\title{
A series of 13 new cases of langerhans cell histiocytosis of the oral cavity: a master of disguise
}

\author{
P. Eden ${ }^{1}$, W.A.M.U.L Abeyasinghe ${ }^{2}$, M.B.M Mufees ${ }^{2}$ and P.R Jayasooriya ${ }^{2}$ \\ ${ }^{1}$ Department of Oral and Maxillofacial surgery, Faculty of Dental Sciences, University of Peradeniya, Sri Lanka \\ ${ }^{2}$ Department of Oral Pathology, Faculty of Dental Sciences, University of Peradeniya, Peradeniya, Sri-Lanka
}

\begin{abstract}
Langerhans cell histiocytosis $(\mathrm{LCH})$ is a disease characterized by clonal proliferation and excessive accumulation of disseminated forms of dendritic Langerhans cells. The aims of thestudy were to describe clinico-pathological presentations of thirteen new cases of LCH of the oral cavity and to present its differential diagnoses. The majority of $61.53 \%(8 / 13)$ of cases occurred in infants and adolescents with female predominance (61.53\%). Out of all the lesions,61.53 \% occurred intraosseously; with majority $53.82 \%$ (7/13) presenting on the posterior mandible and $15.38 \%(2 / 13)$ in the anterior mandible.Five lesions extended to involve more than one site. Radiologically all intraosseous lesions presented as osteolytic lesions with ill-defined or well defined margins. A wide range of clinical differential diagnoses including malignancies have been proposed indicating the aggressive clinical presentations exhibited by some lesions. Histopathologically, all lesions at first glance resembled an infection/chronic inflammatory process and contained mixed inflammatory cells including eosinophils. Deep fungal infections and traumatic ulcerative granuloma with stromal eosinophilia (TUGSE) were the two main histopathological differential diagnoses that were considered for hard tissue and soft tissue lesions respectively. Round mononuclear cells, containing eosinophilic cytoplasms and peripheral indented cerebriform nuclei were only observed under higher magnification. Immunohistochemical investigations with S-100 antibody reveled nuclear and cytoplasmic positivity in mononuclear cells confirming these cells as Langerhans cells. All the patients were treated with complete surgical excision with or without chemo/radiotherapyand are under follow up care. In conclusion, as LCH of oral cavity may have a broad spectrum of clinico-pathological presentations, high degree of clinical awareness is required to arrive at the definitive diagnosis. The histopathological diagnosis is reliable with immunohistochemical confirmation of the Langerhans cell. However, awareness of its differential diagnosis is important to avoid misdiagnosis; resulting in incorrect management.
\end{abstract}

\section{Introduction}

Langerhans cell histiocytosis $(\mathrm{LCH})$ is one of the histiocytosis syndromes; that can occur at any age and is characterized by local proliferation of disseminated forms of dendritic Langerhans cells [1]. It was named after the appearance of the cells, which resemble the normal dendritic cells first noted by Paul Langerhans in 1868 [2]. The disease has been identified by several names, including Hand Schullar- Christian disease, Letterer-Siwe disease and Histiocytosis X, until it was renamed in 1985 by the histiocyte society as Langerhans cell histiocytosis [3].

The cause is unknown but it may be a disorder of immune regulation.It may be caused by a dysfunction of immune system, representing a hypersensitive reaction to an unknown antigen, with stimulation of the histiocytes macrophage system [4].

Organs such as lungs, liver, lymph node, spleen, haematopoietic tissue and muco-cutaneous tissues may be affected. The involvement of jaws (particularly the mandible) is not unusual [5]. In oral mucosal involvement, mucosal ulceration is typically associated with lesions of underlying bone [6]. According to Histiocytic society, LCH was categorized in to 6 sub groups namely unifocal disease, multifocal single system disease, congenital self-healing $\mathrm{LCH}$, multi focal multi system disease, pulmonary type and secondary LCH associated with neoplasms; depending on the number of lesions and sites involved $[7,8]$.

LCH is predominantly a childhood disease that affects 5 children per million, most prevalent in Caucasians and affects males twice as often as females $[9,10]$. LCH is known to mimic many other conditions. Its diagnosis is especially difficult due to its wide clinical spectrum, ranging from single lesion to a multi-system disorder. There are many reports about the misdiagnosis of this disease [11].

LCH is diagnosed by clinico-pathological correlation, with the histological presentation as the common characteristic across disease categories. Langerhans cells are composed of eosinophilic to amphophilic cytoplasm, and contain deeply indented, cerebriform nucleus. It is confirmed with reactivity of S-100, CD1A or CD 207 antibodies [12]. In majority of patients LCH is a self-limiting process, although often with alternating phases of relapse and remission. In general, it is considered that the younger the patients, the worse the prognosis [13]. Multidisciplinary treatment approach is vital for correct diagnosis and treatment, with routine examinations and long term control of these patients for the periodic follow-up of the disease [14].

\section{Materials and methods}

All cases diagnosed during the period from 2007 to 2016, as LCH

Correspondence to: P.R Jayasooriya, Department of Oral Pathology, Faculty of Dental Sciences, University of Peradeniya, Sri Lanka; Tel: +94-81-2397439, Fax: +94-81-2388948; E-mail: primalij@yahoo.com

Key words:Langerhans cell histiocytosis; oral cavity; radiolucency; adolescence

Received: December 20, 2016; Accepted: January 23, 2017; Published: January 26,2017 
were retrieved from the files of the Department of Oral Pathology, Faculty of Dental Sciences, University of Peradeniya.

Clinico pathological presentations of the thirteen lesions were obtained from surgical and pathological records. All 13 slides were reviewed by one author (PRJ) to confirm the diagnosis of $\mathrm{LCH}$.

\section{Results}

\section{Clinical and radiological presentations}

Clinicopathological features of LCH are summarized in Table 1.

Table 1. Clinicopathological presentations of 13 cases of LCH.

\begin{tabular}{|c|c|c|}
\hline Feature & Number & $\%$ \\
\hline \multicolumn{3}{|l|}{ Age (years) } \\
\hline $0-5$ & 3 & 23.07 \\
\hline $6-15$ & 5 & 38.46 \\
\hline $16-25$ & 1 & 7.69 \\
\hline$>26$ & 4 & 30.77 \\
\hline Age range- 4 months -46 years. & & \\
\hline \multicolumn{3}{|l|}{ Gender } \\
\hline Male & 5 & 38.46 \\
\hline Female & 8 & 61.54 \\
\hline \multicolumn{3}{|l|}{ Sites involved* } \\
\hline Posterior mandible & 7 & 53.84 \\
\hline Anterior mandible & 2 & 15.38 \\
\hline Posterior maxilla & 2 & 15.38 \\
\hline Anterior maxilla & 1 & 7.69 \\
\hline Gingiva & 1 & 7.69 \\
\hline Palate & 2 & 15.38 \\
\hline Buccal mucosa & 1 & 7.69 \\
\hline Tongue & 1 & 7.69 \\
\hline \multicolumn{3}{|l|}{ Symptoms at presentation* } \\
\hline Mass/lesion & 6 & 46.15 \\
\hline Pain & 2 & 15.38 \\
\hline Mobile teeth & 5 & 38.46 \\
\hline Oral ulcer & 3 & 23.07 \\
\hline Impaired healing & 1 & 7.69 \\
\hline Gingival bleeding & 2 & 15.38 \\
\hline No significant symptoms at presentation & 2 & 15.38 \\
\hline \multicolumn{3}{|l|}{ Extra oral symptoms at presentation } \\
\hline Soft tissue lesion only & 3 & 23.07 \\
\hline Soft and hard tissue lesion. & 1 & 7.69 \\
\hline Fever & 1 & 7.69 \\
\hline Skin lesions & 1 & 7.69 \\
\hline No extra oral symptoms at presentation & 7 & 53.84 \\
\hline \multicolumn{3}{|l|}{ Intra osseous/ Extra osseous involvement } \\
\hline Intra osseous lesions & 8 & 61.54 \\
\hline Extra osseous lesions & 4 & 30.77 \\
\hline Intra osseous and extra osseous lesions & 1 & 7.69 \\
\hline \multicolumn{3}{|l|}{ Clinical impressions* } \\
\hline Langerhan Cell Histiocytosis & 2 & 15.38 \\
\hline Eosinophilic granuloma & 3 & 23.07 \\
\hline Radicular cyst & 1 & 7.69 \\
\hline Odontogenic Keratocyst & 2 & 15.38 \\
\hline Dentigerous cyst & 1 & 7.69 \\
\hline Infected cyst & 1 & 7.69 \\
\hline Odontogenic tumours & 4 & 30.77 \\
\hline Malignancies & 2 & 15.38 \\
\hline Osteosarcoma & 1 & 7.69 \\
\hline Acute Necrotizing Ulcerative Gingivitis & 1 & 7.69 \\
\hline Intra bony heamangioma & 1 & 7.69 \\
\hline Ewings Sarcoma & 1 & 7.69 \\
\hline Aggressive Central Giant Cell Granuloma & 1 & 7.69 \\
\hline
\end{tabular}

*Please note that symptoms at presentation, sites involved and clinical impressions given does not add up to 13 as more than one symptom/clinical impression had been included for some cases. In addition in 5 cases more than one site was involved
The patients' age at presentation ranged from 04 months - 46 years. A female predilection (8/13) with male to female ratio of $1: 1.6$ was observed. Majority of LCH (11/13) showed a wide range of clinical presentations and symptoms including swelling (Figure 1), ulceration, and fever and bleeding. Only two lesions were observed as incidental findings and these were asymptomatic. Out of all the lesions, $61.53 \%$ occurred intra-osseously; with majority $53.82 \%(7 / 13)$ presenting in the posterior mandible and $15.38 \%(2 / 13)$ in the anterior mandible. Only $23.1 \%(3 / 13)$ occurred in soft tissues of tongue, buccal mucosa and gingiva. Five lesions extended to involve more than one site. Radiologically all intraosseous lesions presented as osteolytic lesions with ill-defined or well defined margins (Figure 2). According to classification proposed by the Histiocytic society, five patients were considered to have multifocal single system LCH, one as multifocal multisystem disease and rest as unifocal single system LCH. Lesions of all patients were treated by excision, followed by referral for oncology unit for further management of two patients. Only two patients experienced recurrences.

\section{Pathological features}

Histopathologically, all lesions at first glance resembled an infection/chronic inflammatory process and contained mixed inflammatory cells including eosinophils. Deep fungal infections and traumatic ulcerative granuloma with stromal eosinophilia (TUGSE) were the two main histopathological differential diagnoses that were considered for hard tissue and soft tissue lesions respectively. Round mononuclear cells, containing eosinophilic cytoplasms and peripheral indented cerebriform nuclei were only observed under higher magnification (Figure 3).

\section{Immunohistochemistry}

S-100 antibody revealed nuclear and cytoplasmic positivity in mononuclear cells confirming the presence of Langerhans cells (Figure 4). Thus the diagnosis rendered was LCH for all patients.

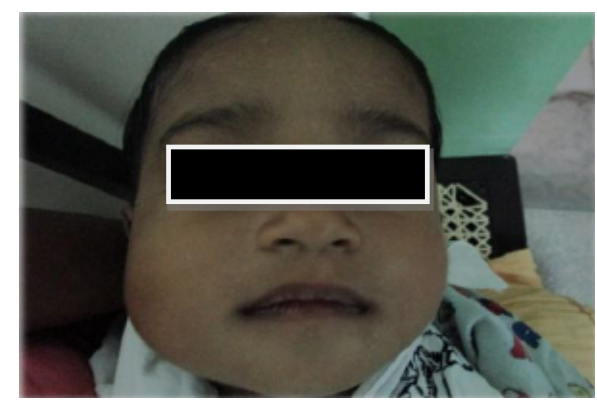

Figure 1. Clinical photograph showing extraoral presentation of the swelling in a one year old child.

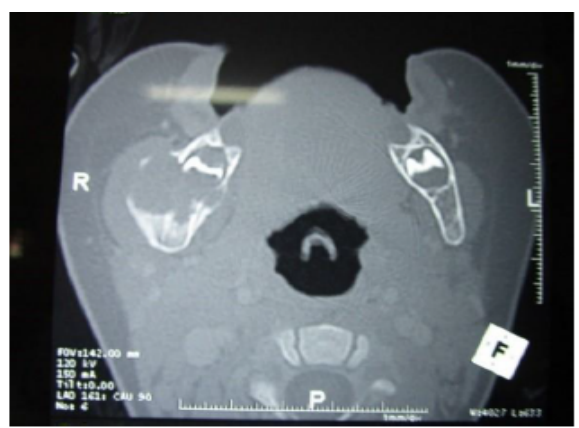

Figure 2. CT view showing destructive bone lesion of the patient mentioned in figure 1 . 


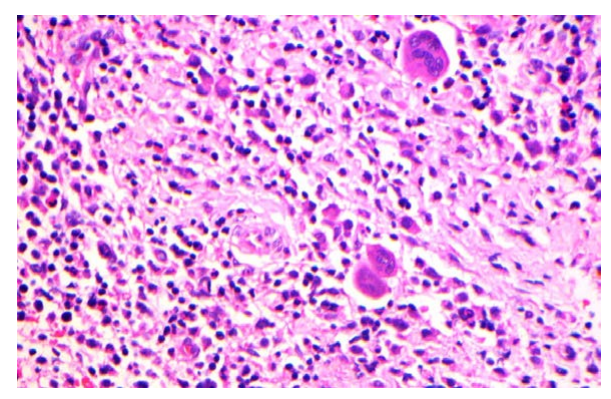

Figure 3. Hematoxylin and eosin stained section of LCH showing a collection of large mononuclear cells with cerebriform nuclei in an inflammatory cell background. A few multinucleated giant cells are also noted (x20)

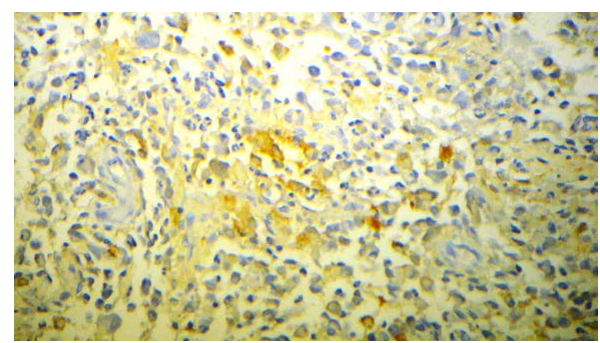

Figure 4. Immunohistochemical investigations with S-100 antibody showing membranous positivity (x20).

\section{Discussion}

Although LCH is a rare entity, it's the commonest disease among the histiocytic diseases [7,9]. Oral involvement is aninfrequent finding. Approximately $10 \%-20 \%$ of initial symptoms and signs are nonspecific oral findings that include: gingival enlargement, oral ulceration,mobility of teeth with alveolar expansion, jaw pain, facial swelling, as well as classic intraosseous lesions and scooped out radiolucencies of the alveolar process [15-17]. Mandibular lesions are commonly associated with the maxillary involvement, but rarely maxillary disease is seen without mandibular radioluciencies [17]. In contrast, no patients in our series showed both mandibular and maxillary involvement. LCH affects patients from neo-natal period to adulthood, although it appears to be more common in children aged $0-15$ years (reported approximately 4 cases per million) [18]. Similar to literature findings majority of the $\mathrm{LCH}$ cases of the present series also occurred in patients aged between $0-16$ years $(71 \%)$. Although, literature indicates that there is a male predilection, in our series female predilection was observed with a male to female ratio of 1:1.6.

The diagnosis of LCH is confirmed by immunohistochemitry. Routine Hematoxylin and eosin stained sections generally reveal mixed inflammatory cells including eosinophils, mimicking a chronic inflammatory process. Electron microscope reveals Birbeck granules in the lesional cells, described as organelles with rod-shaped or tennis racket like morphology that could represent structural changes of the membrane following contact with an antigen. Use of immunohistochemical techniques shows positivity to S-100 and CD1a markers and demonstrate APTase activity of the cellular membranes of the mononuclear histocytic cells [19-21]. Although, both CD207 and CD1A antibodies are more reliable than S-100 antibody to confirm $\mathrm{LCH}$, unavailability of former monoclonal antibodies prevented it been used to confirm the diagnosis in the present case series [22].

LCH should be treated surgically and only complemented with lower dose radiotherapy. In serious cases, especially in disseminated forms radiotherapy and chemo therapy should be used to treat $\mathrm{LCH}[7,8] \cdot$ In the above case series all cases were managed by surgical excision. Two cases were referred to the oncology unit for further management. In conclusion, this clinical, radiological and histopathological analysis of LCH can be used to create awareness among the clinicians to avoid misdiagnosis while bearing in mind oral manifestations may be the initial or only manifestation of systemic LCH.

\section{Funding support and sponsorship}

Nil

\section{Conflicts of interest}

There are no conflicts of interest.

\section{Informed consent}

Informed consentshavebeen obtained from patients or their guardians at the time that the biopsy was obtained for diagnostic purposes.

\section{References}

1. Ardekian L, Peled M, Rosen D, Rachmiel A, Abu el-Naaj I, et al. (1999) Clinical and radiographic features of eosinophilic granuloma in the jaws: review of 41 lesions treated by surgery and low-dose radiotherapy. Oral Surg Oral Med Oral Pathol Oral Radiol Endod 87: 238-242. [Crossref]

2. Leonidas JC, Guelfguat M, Valderrama E (2003) Langerhans' cell histiocytosis. Lancet 361: 1293-1295. [Crossref]

3. (1987) Histiocytosis syndromes in children. Writing Group of the Histiocyte Society. Lancet 1: 208-209. [Crossref]

4. Ardekian L, Peled M, Rosen D, Rachmiel A, Abu el-Naaj I, et al. (1999) Clinical and radiographic features of eosinophilic granuloma in the jaws: review of 41 lesions treated by surgery and low-dose radiotherapy. Oral Surg Oral Med Oral Pathol Oral Radiol Endod 87: 238-242. [Crossref]

5. Milian Masanet A, Bagán Sebastián JV, Basterra Alegría J, Jimênez Soriano Y, Lloria de Miguel E (1996) [Oral histiocytosis X with severe upper maxillary destruction]. Acta Otorrinolaringol Esp 47: 475-478. [Crossref]

6. Cleveland DB, Goldberg KM, Greenspan JS, Seitz TE, Miller AS (1996) Langerhans' cell histiocytosis: report of three cases with unusual oral soft tissue involvement. Oral Surg Oral Med Oral Pathol Oral Radiol Endod 82: 541-548. [Crossref]

7. Hicks J, Flaitz CM (2005) langerhans cell histiocytosis: current insights in a molecular age with emphasis on clinical oral and maxillofacial pathology practice. Oral Surg Oral Med Oral Pathol Radiol Endod 100: 542-566. [Crossref]

8. Mc clain KL (2004) Langerhans cell histocytosis: what is the orphan telling us? Hematology. 84-7.

9. Weitzman S, Egeler RM (2008) Langerhans cell histiocytosis: update for the pediatrician. Curr Opin Pediatr 20: 23-29. [Crossref]

10. Sellari-Franceschini S, Forli F, Pierini S, Favre C, Berrettini S, et al. (1999) Langerhans cells histiocytosis. Int J Pediatr Otorhinolaryngol 48: 83-87. [Crossref]

11. Chen N, Peron JM (2000) [The nonhealing of the buccal mucosa after tooth extraction. Apropos a case of histiocytosis X]. Rev Stomatol Chir Maxillofac 101: 33-35. [Crossref]

12. Weber-Chappuis K, Thorens B (1997) [Histiocytosis X falsely diagnosed as silicosis]. Rev Med Suisse Romande 117: 901-905. [Crossref]

13. Duncan WK, Post AC, McCoy BP (1988) Eosinophilic granuloma. Oral Surg Oral Med Oral Pathol 65: 736-741. [Crossref]

14. Mandrigal-Martinez-Pereda C, Guerrero-Rodriguez V, Guisado-Moyor B, MenizGarcia (2009) Langerhans cell histiocytosis; Literature review and descriptive analysis of Oral manifestations. Med Oral Patol Oral Bucal 14: E222-8.

15. Ladisch S, Jafe E (1993) Principals and practice of pediatric oncology, 2nd Ed. Pizzo PA, Poplack DG, eds. Philadelphia: JB Lippincott co,617-28

16. Hartman KS (1980) Histiocytosis X: a review of 114 cases with oral involvement. Oral Surg Oral Med Oral Pathol 49: 38-54. [Crossref] 
17. Dagenais M, Pharoah M, Sikorski P (1992) radiographic characteristics of histiocytosis X: a study of 29 cases that involves the jaws. Oral Surge Oral Med Oral Pathol 74: 230-236.

18. Windebank KP, Nanduri V (2009) Langerhans cell histiocytosis. Arch Dis child.

19. Milián MA, Bagán JV, Jiménez Y, Pérez A, Scully C, et al. (2001) Langerhans' cell histiocytosis restricted to the oral mucosa. Oral Surg Oral Med Oral Pathol Oral Radiol Endod 91: 76-79. [Crossref]
20. Mejia R, Dano JA, Roberts R, Wiley E, Cockerell CJ, et al. (1997) Langerhans' cell histiocytosis in adults. J Am Acad Dermatol 37: 314-317. [Crossref]

21. Stewart JC, Regezi JA, Lloyd RV, McClatchey KD (1986) Immunohistochemical study of idiopathic histiocytosis of the mandible and maxilla. Oral Surg Oral Med Oral Pathol 61: 48-53. [Crossref]

22. Chickwava K, Jaffe R (2004) Langerin(CD207) Staining in normal pediatric tissues, reactive lymphnodes and childhood histiocytes disorders. Pediatr Dev Pathol 7: 60714. [Crossref]

Copyright: (C2017 Jayasooriya PR. This is an open-access article distributed under the terms of the Creative Commons Attribution License, which permits unrestricted use, distribution, and reproduction in any medium, provided the original author and source are credited. 